\title{
MDG's: Isolating and Understanding its Health Component (4, 5 \& 6) for Successful Action and Sustainability in Nigeria
}

\author{
Akume, Albert. T. \\ Dept. Public Administration \\ C.A.S.S.S. Kaduna Polytechnic, Kaduna. \\ yimaalbert@yahoo.com.
}

\section{Doi:10.5901/mjss.2014.v5n6p441}

\begin{abstract}
The MDGs agenda is aimed at redirecting the focus of government of developing societies to area-specific (social dimension) of human development for proper intervention so as to effectively confront and eliminate those conditions that undermine human capacity to express and utilize their potentials for better living. With just few years to the target year of 2015 Nigeria's performance towards the achievement of the MDG health targets remains an issue for concern, given that health and health related issues are important to human, economic and national development. This is premised on the fact that health influences economic growth by drastically reducing production loss from man-hour losses due to poor health condition. It is against this backdrop that this paper using the documentary method examines the core issues relating to its challenge, success and sustainability of the MDG health components in Nigeria.
\end{abstract}

Keywords: MDG, Health Component (4, 5 \& 6), Development, Social Development, Poverty and Wellbeing.

\section{Introduction}

The desire by both the developed and developing nations to change the abhorring social and economic conditions that confront third world nations citizens has made social development a core issue of governance in developing societies. The desire to improve social conditions is stimulated by the deplorable impoverished living condition which citizens of developing societies are daily confronted with. It is argued that the escalating development gap is due to the existing economic exploitation between the developed and developing nations with the ratio at 3:1 is to be blamed for the poverty trap and the less than appreciable living conditions in developing societies. Others associate the poor socio-economic conditions of developing societies to the prevailing bad governance in those societies. To others, the situation is so because most of those countries possess limited resources and for some, due to their governments' inability to make good use of even the limited investible resources they do possess. These factors explain why poverty, inequality and unemployment persist in developing countries.

Whatever is the cause of those poor conditions there is the need to eliminate them as well as close the development gap between developed nations and the developing world. This demand has provoked the need to ensure that developing nations have control, exploit and fully utilize their resources for the good of their citizens. This need is premised on the belief that if developing societies are able to improve their economies and the living conditions of the citizens, it will in turn reduce significantly the migration problem now been experienced by developed world. It is for this reason that the developed nations through the UN institution have continue to seek for the best development alternative for third world nations.

In this millennium, the search for better human conditions have been designed and capsuled in the MDGs by the North and adopted by the South as a panacea for mitigating the less than appreciable development efforts of the latter. This effort was in part stimulated by the UNDP - World Bank human development reports of 2000, 2003, 2009 and other subsequent publications that have not failed to draw the world's attention to the abhorring social development indicators of most developing societies. Although, Nigeria is richly endowed, her socio-economic and human development indices are unacceptably poor. To be specific, Nigeria has a human development index of 0.453 , life expectancy at birth is 43.3years, and over (sixty) $60 \%$ of the population are living below the poverty line with high incidence of disease (see Otobo, 2002). Out of the total population which is approximated at 150 million only about $60 \%$ of Nigerians have access to primary health care (Anger, 2010:140) services that is substandard and not comparable to international standard despite having those institutions. 
Infant mortality is 77 per 1,000 and maternal mortality stands at 704 per 1,000 live births; this is one of the highest in the world (Chukwuemeka, 2009:409). Nigeria is still among one of those countries with the lowest level of immunization coverage and growth monitoring. The poor level of immunization and growth monitoring is responsible for the high level of under-five morbidity and mortality rate that stands at 250 per 10,000 (Abosede, 2010:1). Comparatively, Nigerian has the highest rate of HIVIAIDS infection in sub-Saharan Africa. The incidence of the epidemic in Nigeria is still high and she is still characterized as having one of the most rapidly increasing rates of new HIVIAIDS cases in West Africa. Nigeria accounts for nearly $10 \%$ of the HIVIAIDS burden in the world, with 4 million of its citizens living with the infection; this is a major health and developmental challenge. Nigeria has the fourth highest TB burden in the world. The prevalence of communicable deceases remains unacceptably high and so also the attendant high mortality that is daily recorded therefrom.

These deplorable social conditions have found expression in underdevelopment. Underdevelopment represents a deplorable and unsatisfactory state of human existence. The enduring socio-economic and political impact of underdevelopment on any society is that it continues to breed poverty, ignorance, diseases, mal-distribution of national income, administrative incompetence and social disorganization (Anyebe, 2011:31). Killick, (1981) emphatically observed that underdevelopment is the chief cause of poverty in developing countries, often aggravated severe degree of inequality. Inequality is symbolic in the perpetuation of poverty and unemployment. These conditions are easily perpetuated because in most developing society's market power is frequently converted into political power which can also be used to reinforce inequalities (Killick, 1981:122).

In Nigeria, the problem of underdevelopment with its negative impact on the living conditions of majority of the citizens is overwhelming now than ever before. It spans a vicious circle between literacy and illness; it is responsible for high morbidity and mortality rates in communities (Abosede, 2010:1) across Nigeria. Poverty, inequality and unemployment are all aspects of underdevelopment and they are all aspects of social injustice. The relationship between them are clearly close (Killick, 1981) in that one element activates the other thus allowing the three to run in a vicious cyclical pattern that further strengthens underdevelopment. Underdevelopment should in part be viewed as a social problem originating in the failure of social institutions rather than in a lack of technical knowledge (Anyebe, 2011:31). Its destructive effect on the citizenry potentials and health thus make a moral case not only for greater efforts to be made to raise the living standards of the people, but also the need to evolve practical solutions (policy options) that will redefine the path of improving access to, and provision better health services to the citizenry so as to not only achieve the health component of the MDGs but to entrench social development. To the precursors of the MDGs, the agenda is the starting point for effectively challenging the social issues that perpetuate underdevelopment.

Social development is concerned with the process of change that leads to improvements in human wellbeing, social relations and social institutions, and that are equitable, sustainable, and compatible with principles of democratic governance and social justices (UNRISD, 2011:1-2). Since the late 1990s there is a demand for evidence of alternative pathways for reducing poverty, protecting the vulnerable, and promoting longer term trajectories of growth that are more socially equitable and sustainable than those of recent decades (UNRISD, 2011:1-2). This development mindset resulted in the birth of an internationally agreed set of development indicators in the form of united nation MGDs (Sumner, 2007:23). The MDGs approach identified eight focal areas upon which federal, state and local government action should be directed at. The UN and other development partners are of the belief that achieving these goals will have a positive consequence on social and human development.

With the emergence of the MDG goals, development has been refocused on the individual as the center piece for change. Central to the MDGs 'road map' are health and economic related concerns. For this paper, achieving the health concern of the MDG 4, 5 and 6 listed below, that is, iv) reduce child mortality, v) improve maternal health, vi) combat HIVIAIDS, malaria and other disease, is central to strengthening the economic potentials and wellbeing of the citizenry. Pursuing these goals is quite symbolic for the Nigerian state given the abhorring human conditions most Nigerians are forced to live with; which has continued to raises public concern. Hence, the objective of this paper is to briefly examine those conditions that could facilitate as well as inhibit Nigeria's efforts to achieve and sustain the health components of the MDGs for better social welfare and wellbeing of Nigerians.

\section{Development, MDG and Health: Capturing their Conceptual Link}

Development is a social, economic and political desirable state. It conceptualization has been fraught by conflicting opinions due to differences in perception. Changes in perception of development in the extant literature have over time swingged to the tune of changing times and challenges associated with the focus and weaknesses associated with the previous definition of development. Even the classification of development definitions is no less problematic. For the first 
group, the various conception of development can be frozen into two distinctive groups. The first group focus on the attainment of economic progress, while the second group places emphasizes on the individual as the essence of development.

Development to the latter group is conceived in terms of human well-being rather than as the state of the national economy (Onah, 2006:15). While for the former group, development is seen in terms of the structure and growth of the national economy. It is foolhardy to contest the fact that a nation's improved economic indices is an essential precondition for enhancing human development index, if government policy is deliberately aimed at ensuring that better economic conditions should not exploit but yield valuable outcome for the people. It is noteworthy to concede that real development does not only capture economic parameters, but it also seeks to improve and unbind people from those conditions that are perceived to limit their wellbeing; this is the essence of development.

The second group are of the view that

\begin{abstract}
there are three discernable definitions of development: the first is historical and long term and arguably relatively valuefree-development as a process of change. The second is policy related and evaluative or indicator led, is based on value judgments, and has a short-to medium-term time horizon- development as the MDGs, for example. The third is post-modernist, drawing attention to the ethnocentric and ideologically loaded Western conceptions of development and raising the possibilities of alternative conceptions (Sumner, 2007:11).
\end{abstract}

These differences notwithstanding, some scholars have made remarkable progress in reconciling the differences in definition. The synthesis of the dimensions of development encapsulating Martha Nussban: basic human capabilities, Manfred Max-Neef: axiological categories, Deepa, Narayan et al: dimension of wellbeing, Shalom Schwartz: universal human values, Robert Cummins: quality of life domains, Maureen Ramsey: universal psychological needs, and Doyal and Gough: basic human needs by Alkire, (2002:187-194) does not only evidence this integrative effort but also magnify the relevance of evolving a one-fit definition of development to capture contemporary conditions. This pursuit is essential in helping government, scholars and development institutions to tackle effectively the global campaign against poverty, and concerns with social protection and employment that have re-emerged on the policy agenda for which alternative conception have been wanting, if not contradictory from the perspective of social development (UNRISD:2011).

Inferring from the above, this paper will anchor on the conceptual view of development offered by Killick, (1981) and Todaro and Smith, (2005). According to Killick, (1981:24) development is essentially a process of structural change, resulting in radical transformations in patterns of demand and output, and in the physical and institutional framework. Taking it a little further Todaro and Smith, (2005:51) are of the view that development is

\begin{abstract}
a multi-dimensional process involving major changes in social structures, popular attitudes, and national institutions, as well as the acceleration of economic growth, the reduction of inequality, and the eradication of poverty. Development, in its essence, must represent the whole gamut of change by which an entire social system, tuned to the diverse basic needs and desires of individuals and social groups within that system, moves away from a condition of life widely perceived as unsatisfactory toward a situation or condition of life regarded as materially and spiritually better.
\end{abstract}

Put together, the above summarily reflect the view of Goulet, (1971) and Sen, (1984), According to Sen, (1984) development should enhance the entitlements and capabilities of individuals in society. The value of the above observation is most appreciated only to the extent that the basic needs of the citizenry are met in such a manner that the three core values of life sustenance, self esteem and freedom (Goulet, 1971) of the citizenry are not obliterated. To this end, it can also be said that development has a psychological dimension goals which should not be ignored but be taken care- off as both the government and the private economic system provide for the citizens the right platforms that allow them to acquire greater skills and capacity, creativity, self discipline, responsibility and material wellbeing (Rodney, 1971:9) (whether it be objective, subjective or context-specific wellbeing (Sumner, 2002) it is essential that development should curb, if not, eliminate poverty, unemployment and inequality in society. Summarily,

Development is much more than economic growth which is only a means of enlarging those choices by building human capabilities. The most basic capabilities for human development are to lead long and healthy lives to be knowledgeable, and to have access to the resources needed for a decent standard of living, and to be able to participate in the life of the community (UNDP, 2001).

There are significant numbers of theories that illuminate the concept of development. These theories include: dependency theory, world system theory, the state theory, modernization theory and the human development theory. This theory combines older ideas of ecological economics, sustainable development welfare economics, and the feminist 
economics (Omodeyi, 2008:8). Available development theories that are captured in the development literature represent valued lighthouse that lite the path of human struggle to evolve the best desirable way of understanding, pursuing, attaining and sustaining progressive change in society.

Whether definitional or theoretical exegeses, it is essential that real development should not only capture economic progress but reinforce the evident truth that it is now an acceptable orthodoxy that meaningful development should be people-centred (Nkom, 2001:43). And so, it should focus on raising the living standard of the mass of the population (Killick, 1981:107) in progressively desirable ways that incorporate the values of social welfare, equity and justice (Bujra.com, 2012 as cited in Aigheyesi and Omonkalo, 2012:190). These perspectives concur with the dimension of contemporary development, definined broadly in the normative sense of improvements in social wellbeing, social institutions and social relations (UNRISD, 2011).

The question then is which ideological path should be used to eliminate those deplorable human conditions that facilitate the perpetuation of underdevelopment in society? This question does not only raise the fundamental concern of who should lead the change process but by what mechanism. It also pushed to the fore the two dissimilar underlying arguments that have confronted economist, administrators and politicians as they seek to solve the problem of underdevelopment. The one set of group are of the view that the best mechanism for resolving the underdevelopment problem of any nation rest with the efficient production and distribution of resources of the free market system "static efficiency" (Killick, 1981:21).

The idea that the free market system has the capacity to facilitate the development of developing societies by first transforming their economies which will in turn positively impact the living conditions of the citizens has however been faulted by the fact that the free market is grossly deficient to fairly and efficiently allocate resources among citizen. In short, some are of the view that the free market system is responsible for the perpetuation of the poverty trap. The second set of argument is built from the weakness associated with the free market system. Those associated with this group argue that the free market is inherently unstable, responsible for self-reinforcing inequalities which is socially unjust, and that the free market on it own lacks the capacity to birth static efficiency, eliminate the ill-effect of monopoly power and other impediment to economic growth in the economy.

Given these weaknesses, this group is of the view that the state (government) should lead the development process. In spite of the plausibleness of each group's argument the principal conclusion to draw from the above is that there is no a priori presumption of the superiority of either market or governments. Market failures are relative; not absolute, and the same is true of the deficiency of state (Killick, 1981) (government). It is then appropriate to observe that by re-freezing the focus of development to human development which is not the direct objectives of economic investment is valuable in understanding and appreciating the respective roles of participatory processes, and market and political and institutional systems in promoting it (Alkire, 2002:194).

A synthesis of these views and comparing those evident issues of development to the Nigerian scenario only reveals a worrying concern because of their evident absence. The absence of these important development indices in the way Nigerians live has placed much strain on national government to create the necessary change through conscious policy design and implementation that will trigger the transformation of the overall fabric of national life. It is for this end that the MDG framework of action was adopted to aid the emancipation of national economy from the grip of underdevelopment. The MDGs is important because it directs the attention of government to the fundamental areas of state intervention in order to achieve the goal of human development. Attaining this goal requires a governance dimension that is willing to nurture, foster, and entrench a stable democratic value, while at the same time, strengthen her public administration (Otobo 2002) institutions to have the capacity of advancing human capital development.

The problem of Nigerians poor health indices cannot be divorced from the consequence associated with persistent crisis, lack of appropriate education, poor management of public funds, inapt government administrative system, infrastructure decay, policy inconsistent and constant regime changes. These conditions are responsible for entrenching poverty, with its severe implication on the health conditions of most Nigerian. Based on this reality, the goals of MDGs is to assist developing nation raise their capacity to provide the enabling environment that will facilitate the attainment of the most compelling of human desires-a world free of poverty and free of the misery that poverty breeds (Thirwall, 2003:14).

Poverty refers to an abject state of being in which an individual is incapable of utilizing resources around him to improve himself economically, socially, politically or otherwise. It also relates to man's inability to afford decent food, shelter, clothing and recreation (UNDP 1996, Omideyi, 2008:4-6, Anger, 2010:1-2 and Abosede, 2010:1). The saddening consequence is that poverty has continued to create the problem of health and other health related challenges, calorie intake deficit that is estimated to be less than 2 percent of the world cereal production. It is argued that the problem of malnutrition and poor health in developing world are perhaps even more a matter of poverty than of food production (Todaro and Smith, 2005:87). The saddening impact of this problem is reflected in high rate of reduced life expectancy of 
Nigerians.

Although relative, poverty is a worldwide phenomenon that continues to undermine human development potentials. According to Halidu, (1986:160) poverty is caused by difference in ability, the absence of education and training, factor endowment and the absence of access to opportunity (see also, Omideyi, 2008:4-6 and Chukwuemeka, 2009:405). The picture in Nigeria is disturbing as social indicators are well below the accepted average with half of the population living below absolute poverty lines. Life expectancy is only 52 years and infant mortality rate is as high as $84 \%$ per 1000 live birth. It is for this reason that the basic need approach focus on alleviating poverty by promoting opportunity, facilitating empowerment and enhancing security (Thirwall, 2003). By guaranteeing these the state is sure of ensuring that basic needs leads to a higher level of productivity and income through human development in the form of educated and healthy people (Jhingan, 1998:11).

The inability of Nigerian government to improve her governance environment has entrenched unpleasant socioeconomic conditions that have strengthened and entrenched poverty. The consequence associated with poverty is that it has reduced significantly the people's capacity to access better health service hence, further devaluing the level of human development index in Nigeria. Human development is a measure of the total progress and achievement made in a country, which predisposes the people in that country to better standard of living (Okafor, 2004:1). Human development index is characterized by long and healthy life; life expectancy at birth, knowledge, and a decent standard of living. These elements are strongly related and gives meaning to the basic need approach. They are mutually reinforcing in defining whether a country is developed or developing or underdeveloped. It is for this purpose that Human development aims at creating an environment in which people can develop their full potential and lead productive, creative lives in accordance with their needs and interest (UNDP, (2001).

\section{Health as a Social Development Indicator: Meaning, Value, and Issues.}

Health is the invisible force that propels the individual's physical and creative energies to accomplish task, without it a human being is rendered impotent and incapacitated. Its value is inestimable and immeasurable; it is nature's free gift to humans. This unseen force must be maintained continually to keep the soul and the body active. It is core to growth though seldom noticed. Health is the complete state of physical, mental and social wellbeing and not just the absence of illness (Chika, 2008:354). A sound healthy body is the base for longevity, activity and productivity. According to Health, (2001) as cited by Chika, (2008:355)

improving the health and longevity of the poor is not an end in itself, but a fundamental goal of economic growth and poverty reduction... The burden of decease in some low income countries, particularly sub-Saharan Africa stand as a stark impediment to economic growth and therefore must be addressed frontally and centrally in comprehensive strategy.

Any nation or government that neglects the health of its citizen is inadvertently fracturing the robust engine that is responsible for accelerating the growth of its national economy. Health is a vital component of social and economic development; this is premised on the fact that health influences economic growth by drastically reducing production loss due to workers illness, lower rate of absenteeism and raises productivity level (Chika, 2009:355). The importance of health to development no doubt provoked its inclusion as a fundamental element in defining social development hence its inclusion in the MDGs. Social development requires effective and accountable state, institutionalization of rights, sustained public engagement, and type of politics that empower groups, such as the poor and marginalized to exercise influence in how policies are made and how resources are allocated (UNRISD, 2011:12).

The long period of misrule in Nigeria systematically undermined these elements. It is now however evident that with the emergence of liberal democratic since 1999 government policy reform for effective state with progressive social agendas and active citizenship remain disappointing cannot be out rightly disputed but it is also evident that the erstwhile open character of anti-people politics is slowly but gradually declining. Hence, at the local level, the government has made efforts to improve if possible to meet the health needs of the people through an articulated National Health Policy (NHP) with an average three (3) percent annual budgetary allocation. The $3 \%$ allocation however fall short of the average 5 percent proposed by WHO for a better national health care financing considering the large size of Nigeria's population (Aregbeyen, 2004:217-218 and Kamorudeen, 2012:61). He further noted that the NHP through the Primary Health Care $(\mathrm{PHC})$ is to address the main health problems in the community by providing promotive, preventive, and rehabilitative services (Aregbeyen, 2004:216).

The question however is why has the health indices of Nigerian nose-dived despite the elaborate and flamboyant 
national measure? Simply put bad governance and corruption (Aigheyesi and Omonkalo, 2012:191), nonetheless, is the hitherto lukewarm attitude of government (Chika, 2008) toward proper health sector financing (Kamorudeen, 2012:61) are factors responsible for the poor health indices of Nigerians. These factors account for government seemingly unwillingness to acknowledge the important role of health infrastructural facility availability and accessibility to poverty reduction and national development. Regardless of government lukewarm attitude evident in poor policy implementation and monitoring of its articulated health policy, heath is a key driver of economic growth and development for which the government must take serious than it is presently doing if it hope's to better the citizens social indicators.

The social determinant of health of a population is influenced by the following factors, which are: transportation, access to health facilities, urban-rural migration, lack of money, level of education, cultural and religious inhibitions, lack of information and the need to obtain permission from some authority figure, gender inequality and unemployment (see HEFRON, 2010:3-4). The capacity of the government to positively influence these factors and attitudes will significantly improve the health conditions of particularly the rural and urban poor in Nigerian society who lack access to basic health services. Aside from the above, other challenges include: inadequate coverage, inappropriate health orientation, lack of financial sustainability, lack of proper coordination, defective infrastructure and poor logistics support, lack of reliable health data, poor information network and unequal geographical distribution of health facilities and resources. Failing to change these deficiencies through reform is where the major challenge in Nigerian health care provision lies. (For a comprehensive view of Nigeria's selected health and social indicators see Aregbeyen, 2004:221 and the model for health outlay and health outcome see Chika, 2008:357-358).

Given the importance of the health component to the MDG, social and human development the performance of African countries in reaching the millennium development goals cannot be but far from impressive (Omideyi, 2010:12). This is because for component 4, civil disturbance and HIVIAIDS have continued to raise the rate of infant and child mortality in many countries. For component 5, brain-drain of professional health worker to Europe and America has caused the short supply of skilled attendants (Wikipedia, 2011:2) to man the available health facilities, while component 6 is hampered by the reverse in life expectancy especially in sub-Saharan Africa due to poverty and lack of access to even the poorly maintained health facilities. A saddening dimension to the above challenges is that the health components of the MDG's are to be tackled with total respect to intellectual property rights and extreme privatization. If the government is to follow through with these conditions given the high level of people living below the poverty line no one in Nigeria will be able to of a certainty propose a balance sheet of the achievement of the health component of the MDG's in Nigeria in particular and Africa in general because of visible presence of

inequalities that result in part from the enclave structure of most African economies, which concentrates economic activity in the extractive and commodity-producing sector with limited spillover to other sectors, such production patterns generate few jobs, concentrates wealth in resource-rich-sectors, encourage inequality and sow seed of social unrest (UNECA, 2013:vii).

\section{The MDG's as a Basis for Social Development: Reflecting the Issues?}

At the core of the MDG's framework is the need to assist developing nations like Nigeria raise above her development challenges. According to the UN, (2000) the MDG's have eight goals with a target date of achievement in 2015. It is believed that the MDG's have the capacity to respond to the world's main development challenges. Each of the eight goals addresses an aspect of poverty and therefore should be viewed together as mutually interacting to reinforce and engender development. These goals are to: i) eradicate extreme poverty and hunger, ii) achieve universal primary education, iii) promote gender equality and empower women, iv) reduce child mortality, v) improve maternal health, vi) combat HIVIAIDS, malaria and other disease, vii) ensure environmental sustainability, and viii) develop a global partnership for development. Reclining behind the MDGs are six fundamental values of freedom (MDG 1, 2, 3, 4. 5, 6); equality, (MDG 2); solidarity (MDG 8); tolerance (no corresponding MDG); respect for nature (MDG 7) and shared responsibility (MDG 8) (Sumner, 2007:23).

A careful look at these lists, it is observable that the MDGs cover both health and economic related concerns and yet, they are also valuable yardstick for measuring performance. The MDG is aimed at redirecting the development focus of developing society's governments to some key areas as well as strengthen their capabilities to implement reforms and laws (World Bank 1991, 2000). To donor nations, the MDG's framework was the appropriate channel for funding and accountability. Given this value and utility, even the most ardent critic of the MDG agreed that the agenda was desirable and that nobody in their right mind could disagree with the goals of reducing poverty by half or ensuring environmental sustainability (Google, 2014). The ability of the MDG to knit together the interest of the initiators and those of the 
implementing countries made both parties to perceive the MDG as an agenda that is people-centered (Eze, 2005:153).

Despite the agenda's outward pious regalia, The MDG has been criticized for its lack of adequate consultation and the exclusivity of its initiation, and the associated methodological problem that open it to potential distortionary effect (Sumner, 2007:24). The MDG's is also not free of conflicting data problem; the gross inconsistency with which some sources use these data and others do not, the lack of underlying country time series only point to the lack of reliable data for evaluating the actual success or failure of the MDG agenda in comparative terms. The exclusive focus of the MDG's on poverty and social indicators, at the expense of employment creation, according to (Melamed and Scott, 2011) make them a form of 'welfare colonialism'. It for this reason that Easterly, (2008:32) strongly contends that despite the focus and value of the MDG's the definition and determinations of its goals are unfair to Africa. To this end, the strong conclusion that Africa is missing the MDG's depends on arbitrary and arcane choices as to how you set up the MDG's.

The sturdiest of the MDG's criticism is its strong affiliation to, or the adoption of neo-liberalist orientation. By this submission, the MDG partnership thus becomes synonymous with submission to the demands of the imperialist power. In which case, progress in access to the market is measured by the share of exports in the GDP (an increase in the ratio is thus synonymous with progress regardless of the social price), progress in the conditions of non-discrimination by the reduction in subsidies. The above did not only create the problem of non-compatibility between the ideals of social welfare and that of the free-market but that of acceptability. To activate general acceptability irrespective of this paradox; the new model had to be clothed in a discourse that gives it the appearance of legitimacy. It was necessary to reintroduce the word development but empty it of all meaning thereby covering the real intent; the MDG's framework became part of a series of discourses that are intended to legitimize the policies and practices implemented by the dominant capital and those who support it. Captured within the litany of pious hope the legitimacy of government disappeared, thus, giving way to the emergence of other social hegemonies that make possible the revival of development conceived of social progress, democratic advancement, and the affirmation of national independence within a negotiated multipolar globalization (Google, 2014).

While the West wanted developing societies to see the MDG's as a steppingstone to their development, Samir see it as a grand design with sinister undertone given its orientation, affiliation and the challenges that impede its effective attainment. If this concern is true, what then are the real goals that the West has craftily eclipsed in the MDGs and presented to developing societies to swallow line, hook and sinker without the consultation and involvement of developing societies in its design? According to (Amin as cited in Google, 2014) it is evident that the MDGs agenda is rooted in an exploitative historical process that have sought to entrench on the economies of developing societies liberal economic principles of liberalization, privatization de-regulation and neo-liberalism. It thus holds that in answering the question the real design of the Millennium Goals it appears, sadly, the truth is our worst fears they appear to be no more than a smoke screen for a purposeful exploitative process to further enrich the elite in the North at the expense of the South and indeed humanity (Google, 2014). This truth is no less evident considering the extreme brutal efficiency with which the MDGs were imposed by the North and implemented by governments of the South.

While this observation in part reflects a painful reality, more painful is the fact that in Nigeria, it is evident that the number of people living in shanties, with little access to clean water, healthcare facilities and quality education (Aigheyesi and Omonkalo, 2012:188) is nauseatingly disturbing. In such a polity where significant number of people die daily from avoidable, curable and preventable health challenges due to lack of access to better health care only points to the fact that the MDG's is socially desirable imperative for government to act on given that it will assist in reducing global development disparity (Omideyi, 2008:3). These identified lapses not withstanding, the identification of the basic reason for action which are valid cross-culturally (as reflected by the MDG's) commits one to a broadly realistic ethic (in line with the capability approach), although not, on the face of it, to a single metaphysics (Alkire, 2002:194). In this sense, critic should not totally see the MDG as an agenda that seek to extort the underprivileged but on the society whose government lacks the spirit of progressive politics that alters power relations and creates active citizens and responsive and accountable state (UNRISD, 2011:12).

It should be understood that no plan of action is foolproof even as development pursuit is not a by-product of natural coincidence, it is a consequence of well thought-out and implemented planned change, and some times, this planned change requires borrowing ideas or transfer of knowledge from outside that has proven to yield the right result. If need be, such ideas could be modified to suit local conditions given that different conditions calls for different actions, but the objective is to obtain beneficial result. It was for this purpose that the Obasanjo administration and other subsequent administration after him adopted the NEEDS framework and also pursued purposely reforms of the public service premised on the need to address the problems of public service inefficiency by making it efficient and effective to respond to the demand of the MDG responsibility for implementation and ultimate success (NBS, 2013:37).

There are different approaches to viewing the MDGs framework. Holme, (2010) contends that the MDG's is firmly 
embedded in the human development paradigm of development. His position is tied to the argument that the human development approach anchors its measurement of development entirely on economic growth. Adopting the economic growth yardstick only for measuring development of a polity is absolutely inappropriate given that it discriminate against other important development parameters. Melamed and Scott, (2011) on the other hand argued that the perception of the MDG's should go beyond human development alone. But, It should be viewed in terms of wellbeing and as a human right based approach to development. In which sense, development efforts should seek to develop not only the capacities of the individual to claim and exercise those rights, but also of duty on the part of government to enforce human rights and human wellbeing. It is on the basis of this parameter that most scholars presume that the MDG's success in Africa is less than appreciable (Easterly, 2008:1).

To Melamed and Scott, (2011) the fundamental weaknesses of the MDGs is that it is donor-led, miss out on crucial dimensions of development and neglects the poorest and most vulnerable. Hence, a better view of the MDG's framework should reflect the combine dimensions of human development, wellbeing and human right approaches. This outlook represents the most appropriate receptacles for capsuling the MDG framework. The combination of the various approaches imply different ways of measuring whether progress is being achieved, by utilizing different policy priorities to achieve change thereby maximizing the transmission mechanisms between growth and poverty reduction, but also redistribution through government fiscal policy that is balanced and fair to all groups in the polity.

It then means that government policy must aim to change the conditions that facilitate human incapacity, structures, and procedures that are responsible for poverty generation, poor health provision and inaccessibility in Nigeria. It then follows that any well meaning health policy must focus on availability, accessibility cost consideration and responsive; that equally do not neglect to provide efficient service to the general public in accordance with international standards and best practices. This invariably places on government the need to direct its policies and development strategies towards the poor and marginalize in society. For this agenda to have meaning and acceptability to the people, it must be fine-tuned to fit-in with local conditions that reflect the character of participation and transparency, nondiscrimination, equity and equality, empowerment of people through legal and political action and accountability of actor to the governed.

Many reasons have been advanced to be responsible for the poor health indices of Nigerians for which pursuing earnestly the MDG framework (with modification to fit local conditions) to a logical conclusion is a good governance initiative by the government. Significant among these reasons are the prevailing weak primary health care system, external migration of professional health workers, poor health care financing, weak governance structures, poor drugs and medical commodity management, weak information management and growing poverty as a result of rising unemployment, pervasive and institutionalized corruption and the mismanagement of resources (IMF, 1999:1) lethargy, political tension and crises, and bad governance. Generally, Nigeria belongs to the low human development index gap (Mike and Terna, 2010:149). This is a disheartening paradox given Nigeria's enormous human and natural resource endowment (Bello-Imam and Obadan, 2004).

The MDG's constituting elements listed above recognize the interdependence between growth, health, poverty reduction and sustained development. It success is predicated on a sustained foundation of good governance, the rule law, respect for human right, progress, peace and security. These goals can be effectively attained by a combination of domestic and international action (World Bank, 2000). It is in trying to achieve MDG $(4,5 \& 6)$ goals on the domestic front that the MDG framework becomes a significant instrument for planning, policy choice, resource mobilization, implementation, monitoring and evaluation. Nonetheless, is the need for capacity building and proper motivation of health workers in Nigeria to acquire, and utilize new skills and knowledge, and untapped wealth of ideas about how operational procedures of these goals will be ordered? These efforts are significant in stemming the tide of brain-drain or migration of professional or qualified health workers outside this country.

To be effective in attaining some significant progress and sustaining the success of these goals way beyond 2015, public administration must move away from the rigid rule base bureaucratic pattern of management to one that is in tune with result based management, in tune with public needs, flexible and professionally responsive to changing social demands. This focus in part, must allow public-private partnership to flourish in order to achieve the objectives of meeting the health needs the diverse population. While it is essential for the private sector to take the led the government must provide guidance and support on matters relating to MDG $(4,5 \& 6)$ success. Unlike in the past were the public service served as instrument of impeding progress, by failing to act as an effective instrument for the soci-economic transformation of the country (Ezeani, 2005:12).

Equally too, public bureaucrats responsible for monitoring and control as well as health personnel must be ordered by the time honoured "values of loyalty, integrity dedication and competence (Musa, 2001:2). Genuine health service provision must always ensure focus on administrative efficiency coupled with higher quality services delivered to the 
public (Adamolekun and Kiragu 2002). This should be built on the premise that, the true test of good governances is its willingness to strengthen institutional quality to deliver social services that is efficient, responsive, transparent and accountable to all within state jurisdiction.

This focus is central to reinforcing the value of good health delivery to the people within the domain of collaboration driven by the spirit of the MDG. This should form the basis upon which government strategies for achieving the MDGs can be implemented. Hence the need for truly reformed and goal oriented public administration. The significance of public administration reform to the achievement of the MDGs cannot be better captured than in the following words;

First, more resources in poor countries are freed to be used in pursuit of MDG goals if the efficiency of the public administration is increased. Secondly, by increasing transparency and eradication of corruption fewer scarce resources in poor countries will be is directed away from achieving MDGs. Third, a public administration that responds to the need of citizens, especially women and marginalized people, is critical to ensuring the sustainability of the achievement within the rubric of the MDGs. Finally, increasing the accountability of state institution is an essential feature of government strategies to close the democratic strategies to close the democratic deficit, which is key to achieving the MDGs within the context of the broader Millennium Declaration (UNDP, 2000).

\title{
5. Conclusion
}

The truth is that despite public efforts to provide the enabling environment for the attainment of the health components of the MDGs, large section of the Nigerian population still lack access to better health services. This realization should provoke the government through its public institutions the urgent need to provide the enabling environment for the attainment of health goals of the MDGs given that improving the health indices of Nigerians has never been more critical than now. Although, this paper acknowledges the effort of the government through the new national health policy aimed at improving those abhorring conditions, the government still has to do more in the area of mitigating corruption in the health sector as well as intensify its effort in curbing the importation of substandard drugs into the country by unscrupulous businessmen.

In assessing the performance of MDGs in Nigeria, some are of the view that some valuable progress has been made even though absolute success has not been recorded in all areas of the health components. On the contrarily, some are of the view that MDGs have performed below the expectations of Nigerians (Anger, 2010), for which more effort must be intensified to attain or 2015 is not a Nigerian thing; putting everything together (Ezebunwa, 2012:18). Inferring from this mixed opinions, it is essential that the planning of strategies and capacity building for the successful implementation of MDG's health goals $(4,5 \& 6)$ for the remaining year should be non-negotiable. In which case capacity building should focus on further

\begin{abstract}
development of an organization's core skills and capabilities, such as leadership, management, finance and fund-raising programs and sustainability. It is the process of assisting an individual or groups to identify and address issues and gain the insights, knowledge and experience needed to solve problems and implement change. Capacity building is facilitated through the provision of technical support activities, including coaching, training, specific technical assistance and resource network.
\end{abstract}

Evidently, local capacity building must focus at these key areas: i) improving existing and providing new primary health care facilities across the country, ii) motivation and strengthening the skills of available health personnel in the country, iii) strengthening of the infrastructural base and capacity of training institutions in Nigeria for better production of qualified health professional in Nigeria for the benefit of Nigerians, iv) strengthening pharmaceutical regulatory institution for better monitoring and control of pharmaceutical product produced in or imported into Nigeria to ensure they are of high quality and meet international standards.

Considering the evident challenge posed by the failing financial resource of government, it is imperative for the government to evolve a well nested public-private participation framework, which should guarantee genuine mobilization and involvement of the people for successful implementation. This will largely depend on the quality and quantity of the human capital or intellectual capital and the knowledge based management system (Bontis, 1999, Schultz, 1961 and FItzenj, 2000) at the disposal of the federal, state and local government.

Similarly, the nature of relationship between the institutions implementing the MDG health component with the political authorities will play a significant role in the ability of these institutions to effectively influence, garner resources, engineer and implement the strategies for defeating poor health capacity. This is because the countervailing power-play that occurs in the process of policy authorization and appropriation if not properly checked has a destabilizing effect for 
the proper implementation of the MDGs $(4,5 \& 6)$ agenda, given the limited time frame. Since, a statute confers upon an agency only authority to take action on some topic. How effective the agency is, what it actually does or accomplishes, will be affected by the political support it has. To put it differently, politic affects how an agency exercises its discretion and carry out its programme.

Although reform of institutions is a necessary element for success, proper delegation in its true sense must be enhanced and applied without interruption. This is because political interruptions often rear its face to undermine the proper flow of action for implementing institutions. Equally important also is the fact that the environment in which an agency operates may contain many "forces", that at one time or the other exerts influence on its actions. However, if there is carefully planning, proper and adequate mobilization, monitoring and evaluation as implementation continues there is the possibility that the disruptive capacity of those "forces" will be greatly reduced. It is the belief of this paper that the willingness of the government to fully support the public service in the implementation of the MDGs through policy consistency capacity building and funding, success in the MDG's $(4,5 \& 6)$ will be achieved and sustained. This will go a long way in improving health service provision for all Nigerian.

\section{References}

Abosede, O. A. Princess, C.C, Emmanuel, I. K, Ajibike, O. S.A and Anthonia, 0.0 (2010) Sustainable Poverty Amelioration through Early Life Education in a Peri-Urban Community of Lagos, Nigeria. In: African Journal of Primary Health Care and Family Medicine. Vol . 2. No. 1. Pp. 1-7.

Ademolekun, L. and Kiragu, K. (2002) Public Administration Reform. In: Ademolekun, L. (ed) Public Administration in African: Main Issues and selected country studies. Ibadan: Spetrum Books Limited.

Aigheyesi, S. O and O. B. Omonkalo, (2012) Governance and Human Development: Empirical Evidence from Nigeria. In: Journal of Research in National Development. Vol. 10. No. 3b. pp. 188-202.

Alkire, S (2002) Dimension of Human Development. In: World Development. Vol. 30. No. 2. Pp.181-205.

Anger, B. (2010) Poverty Eradication, Millennium Goals and Sustainable Development in Nigeria. In: Journal of Sustainable Development. Vol. 3, No. 4. Pp. 138-144.

Anthony, M. 0. (2010) Building Capacity for Outstanding Service Delivery in Nigeria. In: International Journal of Studies in the Humanities. Vol. 7. No. 8. Pp. 99-110.

Anyebe, A. A (2011) Development Administration: A Perspective on the Challenge in Nigeria. Zaria: Shereef Salam Nig Ltd.

Aregbeyen, J. B. O (2004) Health Policy and Performance .In: Bello-Imam, I. B and Obadan, M. I (ed) Democratic Governance and Development Management in Nigeria's Fourth Republic. Ibadan: CLGARDS. Pp. 210-225.

Bontis, N., Dragonetti, N., Jacobsen, K and Roos, G (1999) The knowledge Toolbox; A Review of the tool Available to Measure and Manage Intangible Resource. In: European Management Journal. Vol. 17. No. 4. Pp. 391-402.

Chika, A. (2008) Federal Government Health Outlay and Health Outcome in Nigeria. In: Journal of International Politics and Development Studies, Vol. 4, No. 1\&2. Pp. 354-361.

Chukwuemeka, E. E. O (2009) Poverty and the Millennium Development Goals in Nigeria: The Nexus. In: Educational Research and Review, Vol. 4. No. 9. Pp 405-410.

Easterly, W (2008) How the Millennium Development Goals are Unfair to Africa. In: World Development. Vol. 37. No. 1. Pp. 26-35

Eze, M.C. (2005) The Millennium Development Agenda and Democracy in Nigeria, 1999-2004. In: Journal of Political Economy. Vol. 1. Num. 1. Pp. 152-162.

Ezeani, O. E. (2005) Administrative Reforms in a Post Colonial State. An appraisal of Nigeria's Experience under Obasanjo Regime (1999 - 2005). In: Journal of Political Economy, Vol. 1 Num. 1. Pp.124-138.

Ezebunwa, E. N (2012) Implications of Gender Inequality for Achieving the Millennium Development Goals by 2015: Is Nigeria Really Making Progress. In: Nigerian Journal of Sociology and Anthropology. Vol. 11. Pp.1-22.

Fitz-enj, J. (2000) The role of Human Capital. American Management Association New York.

Ghai, D.P. (1977) What is a Basic Need Approach to Development All About? In Ghai, D.P. et al (eds), the basic Needs Approach to Development, Geneva, International Labour Organization.

Google, (2014) A Southern Critique of the Millennium Development Goals: A Review of Samir Amins Article. Retrieved on $11^{\text {th }}$ January, 2014 from www.google.com

Halidu, A. (1986) Public Finance, Issues, Principle and Practice, Unpublished.

Jhingan, M. L. (1998) The Economics of Development and Planning (31st ed). New Delhi: Vrinda Publication (P) Ltd.

Hulme, D (2010) Lessons From The Making Mdg : Human Development Meets Result Base Management in an Unfair World. IDS Bulletin. 41 (1). Pp. 15-25.

Kamorudeen, A (2012) The Dilemma of Equity and Social Exclusion in Health Care Delivery Services in Nigeria. In: Nigerian Journal of Sociology and Anthropology. Vol. 11. Pp. 56-68.

Kellick, T (1981) Policy Economics: A Textbook of Applied Economics on Developing Countries: London: Heinemann Educational Books Ltd.

Langford, M (2010) A Poverty of Rights: Six Ways to Fix The MDGs. IDS Bulletin, 41 (1). Pp. 83-91. 
Melamed, C and L. Scott, (2011) After 2015: Progress and Challenges for Development ODI. Retrieved on The 11 January, 2014 from www.odi.org.uk/500years

Mike, O. O and Terna, P. A (2010) Poverty and Democratic Instability in Nigeria since 1999. In: Terhemba, W and Talla N. S (ed) Governance and Economic Development in the Fourth Republic. Makurdi: Aboki Publishers. Pp. 147-165.

Musa, S.A. (2002) Charter for Public Service in Africa: Strategies for Implementation In Nigeria.

NBS, (2013) Millennium Development Goals: Performance Tracking Survey Report 2012. Retrieved on $13^{\text {th }}$ January, 2014 from. www.google.com

Nkom, S. A. (2001) Rural Development as a Springboard for Poverty Alleviation in Nigeria. In: Journal of Political and Economic Development. Vol. Viii, No.1. Pp. 26-50.

Okafor, A. A. (2004) Poverty and Human Development in Nigeria: Challenges of the Millennium development Goals. Nsukka great AP Express Publishers Ltd.

Omideyi, A.K. ( 2008) Poverty and Development in Nigeria: Trailing the MDGs? In: African Journal of Infect. Decease. Vol.1, No. 1. Pp. 3-17.

Otobo, E (2002) Nigeria in L, Adamolekun (ed) Public Administration in Africa: Main issues and selected country studies. Ibadan: Spectrum Book Limited.

Rodney, W (1971) How Europe Underdeveloped Africa. Dares Salaam: Tanzania Publishing House.

Rostow, W.W (1960) The Stages of Economic Growth. Cambridge: Cambridge. University Press

Sen, A. (1984) Poverty and Famines; An Essay in Entitlement and Deprivation Oxford; Claredon Press.

Schultz, T.W. (1961) Investment in Human Capital. In: American Economic Review. Vol. 51. No. 1. Pp. 1-17.

Sumner, C. (2007) What is Development. Retrieved 3 January, 2014 from. www. Google. com

Thirwall, A.P. (2003) Growth and development with Special Reference to development Economics (7ed). New York: Palgrave Macmillan. Todaro, M (2000) Economic Development Report in the Third World. London: Longman

Toradoff, W. Canmack, F.H. and Poo, D. (1993) Third World Politics. Basingstoke: Macmillann.

U.N.D.P. (2001) Human Development Report, 2000. New York: Oxford University Press.

U.N.D.P. (1996) Human Development Report. New York: Oxford University Press.

UNDP. Public Administration Reform: Practice Note. hittp://www.undp.org/policy/practicenotes.htm.

UNRISD (2011) Social Development in an Uncertain World Being a UNRISD Research Agenda 2010-2014. Retrieved 11 ${ }^{\text {th }}$ January, 2014 from www.unrisd.org

UNECA, (2013) Assessing Progress in Africa Toward the Millennium Development Goals. Food Security in Africa: Issues, Challenges and Lessons (MDG Report). Retrieved 13 $13^{\text {th }}$ January, 2014 from www.google.com

Wikipedia, (2011) Health Care in Nigeria. Retrieved from http://en. wikipedia.org/wiki/Health_care_in_Nigeria/

World Bank, (2001) World Development Report 2000/2001 Attacking Poverty. New York: Oxford Ūniversity Press. 
